\title{
A DOUBLE BLIND STUDY TO COMPARE THE EFFICACY OF ALOE VERA GEL AND UNDECYLENOYL PHENYLALANINE 2\% FOR TREATMENT OF MELASMA.
}

1. MBBS, M.Phil

Assistant Professor Pharmacology Sargodha Medical College, University of Sargodha, Sargodha

2. MBBS, FCPS (Dermatology) Assistant Professor Dermatology DHQ Teaching Hospital/ Sargodha Medical College, University of Sargodha, Sargodha

3. MBBS, M.Phil (Pharmacology)

Assistant Professor Pharmacology Central park Medical College, Lahore.

4. MBBS

Physician

Amin Medical Center, Chiniot.

5. MBBS, M.Phil

Associate Professor Pathology Sargodha Medical College, University of Sargodha, Sargodha.

6. MBBS, FCPS

Lecturer Biochemistry

Sargodha Medical College,

University of Sargodha, Sargodha

Correspondence Address:

Dr. Farwa Naqvi

Pharmacology

Sargodha Medical College,

University of Sargodha, Sargodha.

farwashahab@gmail.com

Article received on:

02/12/2019

Accepted for publication:

$19 / 03 / 2020$
Farwa Naqvi', Zaib², Iram Imran ${ }^{3}$, Ahmed Amin Khan Faraz ${ }^{4}$, Tahira Tabussam ${ }^{5}$, Sultan Sikandar ${ }^{6}$

ABSTRACT... Objectives: To compare the efficacy of Aloe vera and undecylenoyl phenylalanine 2\% for Melasma treatment. Study Design: Double Blind Randomized Controlled Trial. Setting: OPD Dermatology Department of DHQ Teaching Hospital, Sargodha Medical College, Sargodha. Period: October 2018 to March 2019. Material \& Method: There were total 120 patients (both male and female) having 60 patients in each group. Patients with melasma were at random allocated either Aloe vera leaf gel and undecylenoyl phenylalanine $2 \%$ at night for 12 weeks. Aloe vera leaf gel and undecylenoyl phenylalanine $2 \%$ were packed in indistinguishable similar tubes numbered 1 and 2 respectively. Neither the investigators who calculated modified MASI score nor the patients was aware which tube carry Aloe vera leaf gel or undecylenoyl phenylalanine $2 \%$. The patients were advised to revisit after every 4 weeks for follow-up for three months. Results: On comparison, the mean of Modified MASI score with treatment with Aloe vera leaf gel was reduced from 17.81 to 17.36. One way ANOVA was applied to compare improvement of modified MASI score at 0, 4, 8 and 12 weeks by applying Aloe vera leaf gel which was insignificant with p-value of 0.535 . Mean of Modified MASI score with treatment with undecylenoyl phenylalanine $2 \%$ was reduced from 18.13 to 4.95 . One way ANOVA was quite significant with undecylenoyl phenylalanine $2 \%$ with p-value of $<0.001$. Conclusion: Undecylenoyl phenylalanine may represent an efficious and beneficial therapy of melasma. Herbal agents which contain Aloe vera and falsely claim that they are effective should be discouraged to treat melasma.

Key words: $\quad$ Aloe Vera, Melasma, Modified MASI Score, Undecylenoyl Phenylalanine.

Article Citation: Naqvi F, Zaib, Imran I, Faraz AAK, Tabussam T, Sikandar S. A double blind study to compare the efficacy of Aloe vera gel and undecylenoyl phenylalanine $2 \%$ for treatment of melasma. Professional Med J 2020; 27(8):1770-1776. DOI: 10.29309/TPMJ/2020.27.08.4459

\section{INTRODUCTION}

Melasma originate from melas, a Greek word for black, or cholas for the word greenish. It is also designated as 'chloasma faciei' and 'pregnancy mask'. ${ }^{1}$ Melasma is a frequent skin ailment of adults resulting in tan or dark blotching on skin. Mostly females with skin group IV to VI are troubled, inhabiting in ultraviolet radiation areas. ${ }^{2}$ The typical site of presentation is face although they may appear on other parts of the body that get lots of sun, such as the forearms and neck. Although it can affect any gender but it is more distressing in women, particularly during pregnancy (when up to $50 \%$ of women may be affected) and females who are on hormonal birth control or hormone replacement therapy (HRT). Around $10 \%$ men may also be affected. ${ }^{3}$
Melasma generally becomes more noticeable in the summer and ameliorates during the winter months. Melasma is disorder instigated by triggering of melanocytes. Mostly, melanocytes reside in the dermal skin layer. Ultraviolet light from the sun stimulates melanocytes, which in turn produce a pigment called melanin, there by aggravating melasma. ${ }^{2}$

The actual mechanism of melasma is not yet lucid. People with skin Skin types IV through VI are more vulnerable to melasma because they have more active melanocytes than people with lighter skin types. ${ }^{4}$ Therefore, genetic inclination is an additional attributing factor in deciding whether anyone will evolve melasma or not. Common melasma triggers include sun 
exposure, change in hormones and allergic reaction to drugs and make-up products. The prevalence of melasma also multiplies in patients having thyroid disease due to unrestrained production of melanocyte-stimulating hormone (MSH).

Melasma has noticeable impact on patient's emotional health and social existence. ${ }^{5,6}$ Traditional therapy of melasma ascertains eradication of any originating influences in conjunction with the application of sunblock lotions and hypo-pigmenting therapy. ${ }^{7}$ Regardless of the deployment of these strategies, melasma is often obstinate to treat. Its prolonged treatment and reoccurrence is devastating for both the patient and the dermatologist. In order to investigate novel therapy for melasma, sound and authentic outcome index are essential to determine clinical gravity of disease. The modified Melasma Area and Severity Index (MASI) ${ }^{8}$, an outcome index evolved in order to establish a better, precise and reliable quantification of degree of melasma and improvement during treatment. ${ }^{9}$

Aloe vera has been tried for centuries to treat different skin ailments. ${ }^{10}$ Research has shown that is quite effective in treatment of skin disorders like mild to moderate acne vulgaris ${ }^{11}$, wound healing ${ }^{12}$, atophic dermatitis ${ }^{13}$ and treatment of squamous neoplasia. ${ }^{9}$ In a recent study Aloe vera gel was used to treat melasma in pregnant females. ${ }^{14}$ Thus, we compared this new herb with undecylenoyl phenylalanine $2 \%$ which has documented efficacy in melasma therapy. ${ }^{15}$

\section{MATERIAL \& METHODS}

This double blind study of the qualified efficacy was carried out at the Outpatient Department of Dermatology, DHQ teaching Hospital, Sargodha Medical College Sargodha. The patients with melasma volunteered in this study were categorized by using non-probability sampling technique. 120 patients aged between 20 and 50 years having Fitzpatrick skin group III, IV and $\checkmark$ with clinical presentation of melasma and with no previous treatment over a period of at least 6 months were selected. Patients who were pregnant, had a recent miscarriage or delivery, or who were availing hormonal treatment in the last six months or any topical formulation for the last 2 months were excluded. Informed written consent was taken. Patients name, age, gender, address and mobile number were noted in a predesigned proforma.

Modified MASI scoring was done to establish the severity of Melasma. Melasma area severity index (MASI) was established by KimbroughGreen for the evaluation of melasma. ${ }^{8}$ The severity of the melasma is computed in areas of face including forehead, right malar region, left malar region and chin. These areas are evaluated according to three features which are percentage of the total area involved (A), darkness (D) and homogeneity $(\mathrm{H})$. A numerical value allocated for the correlating percentage area involved is 0 for no area involved, 1 for $<10 \%$ area involved, 2 for $10-29 \%$ area involved, 3 for $30-49 \%$ area involved, 4 for $50-69 \%$ area involved, 5 for $70-89 \%$ area involved, 6 for $90-100 \%$ area involved. The darkness of the melasma (D) is equated to the normal skin and classified on a scale of 0 to 4 as 0 for normal skin color without sign of melasma, 1 for barely noticeable melasma, 2 for mild melasma, 3 for moderate melasma, 4 for severe melasma. Homogeneity of the melasma $(H)$ is also classified on a scale of 0 to 4 as 0 for normal skin color without sign of melasma, 1 for tiny spots of area involved, 2 for small patchy areas involved $<1.5 \mathrm{~cm}$ diameter, 3 for patches of area involved $>2 \mathrm{~cm}$ diameter, 4 for uniform skin area involved without any clear areas.

To calculate the modified MASI score, the sum of the severity grade for darkness (D) and homogeneity $(\mathrm{H})$ is multiplied by the numerical value of the areas $(A)$ involved and by the percentages of the four facial areas (10-30\%).

Total modified MASI score:

Forehead $0.3(D+H) A+$ left malar $0.3(D+H) A+$ right malar $0.3(D+H) A++\operatorname{chin} 0.1(D+H) A$

Aloe vera plants were purchased from a nursery and identified by Department of Botany, University of Sargodha. Leaves of Aloe vera were completely washed with water and cut to remove the drained 
juice holding aloin. The sides of the leaves were lacerated and then cleaved to release the pulp. The pulp was mixed thoroughly in a blender and strained through muslin cloth. Aloe vera leaf gel prepared was incorporated in a container. ${ }^{16}$ Undecylenoyl phenylalanine $2 \%$ was dispensed from local pharmacy.

Both preparations Aloe vera leaf gel and undecylenoyl phenylalanine $2 \%$ were packed in indistinguishable similar tubes numbered 1 and 2 respectively. It was dispensed by the department nurse. Using simple randomization, patients were allocated either tube 1 or 2 and asked to apply it at night for 12 weeks. The patients were also directed to apply sunblock cream SPF-60 regularly to the hyper-pigmented area during the daytime.

The study was carried out between the months of October 2018 to March 2019. Patients were advised to re-visit after every 4 weeks for followup for a period of 12 weeks to evaluate efficacy of each agent. The modified MASI score was assessed by a single investigator who had no idea what was in tube number 1 or 2 . The MASI score investigator asked the tube number used by the patient and then calculated the MASI score on prescribed performa. Only the dispenser knew the composition of tube numbered 1 and 2. So, neither the investigators nor the patients was aware of the composition of the tube. Clinical efficacy of the two agents was established by improvement of modified MASI index. At each visit, patients were inquired about any adverse effects of the use of the preparations.

Efficacy of Aloe vera leaf gel and undecylenoyl phenylalanine $2 \%$ was shown in in tables and figures. One-way ANOVA was also used to test significance of difference between efficacy of Aloe vera leaf gel and undecylenoyl phenylalanine $2 \%$. $p$ value of $\leq 0.05$ was considered significant.

\section{RESULTS}

There were total 120 patients (both male and female) who were selected for this study. Group $A$ received Aloe vera gel and group $B$ received undecylenoyl phenylalanine $2 \%$.
In group A, there were $48(80 \%)$ females and in group B there were $43(71.67 \%)$ females. Table-I

\begin{tabular}{|l|c|c|c|c|}
\hline \multirow{2}{*}{ Gender } & \multicolumn{2}{|c|}{ Group A } & \multicolumn{2}{c|}{ Group B } \\
\cline { 2 - 5 } & Number & Percentage & Number & Percentage \\
\hline Female & 48 & 80 & 43 & 71.67 \\
\hline Male & 12 & 20 & 17 & 28.33 \\
\hline
\end{tabular}

Table-I. Distribution of patients according to gender

Stratification of age is shown in Table-Il where 67 (55.83\%) out of total 120 patients of melasma majority of patients presented at age between 2130 years of age.

\begin{tabular}{|c|c|c|}
\hline $\begin{array}{c}\text { Age } \\
\text { (years) }\end{array}$ & $\begin{array}{c}\text { Total number } \\
\text { of patients with } \\
\text { melasma }\end{array}$ & $\begin{array}{c}\text { Percentage (\%) } \\
\text { of patients with } \\
\text { melasma }\end{array}$ \\
\hline $21-30$ & 67 & 55.833 \\
\hline $31-40$ & 40 & 33.33 \\
\hline $41-50$ & 13 & 10.83 \\
\hline
\end{tabular}

Table-II. Distribution of patients according to age

Table-III shows mean as well as Standard deviation of modified MASI score at $0,4,8$ and 12 weeks. On comparison, the mean of Modified MASI score with treatment with Aloe vera leaf gel was reduced from 17.81 to 17.36 . One way ANOVA was applied to compare improvement of modified MASI score at $0,4,8$ and 12 weeks by applying Aloe vera leaf gel which was insignificant with $p$-value of 0.535 (Table-III).

Mean of Modified MASI score with treatment with undecylenoyl phenylalanine $2 \%$ was reduced from 18.13 to 4.95 . One way ANOVA was applied to compare improvement of modified MASI score at $0,4,8$ and 12 weeks by applying undecylenoyl phenylalanine $2 \%$, which was quite significant with undecylenoyl phenylalanine $2 \%$ with $p$-value of $<0.001$ (Table-III). 

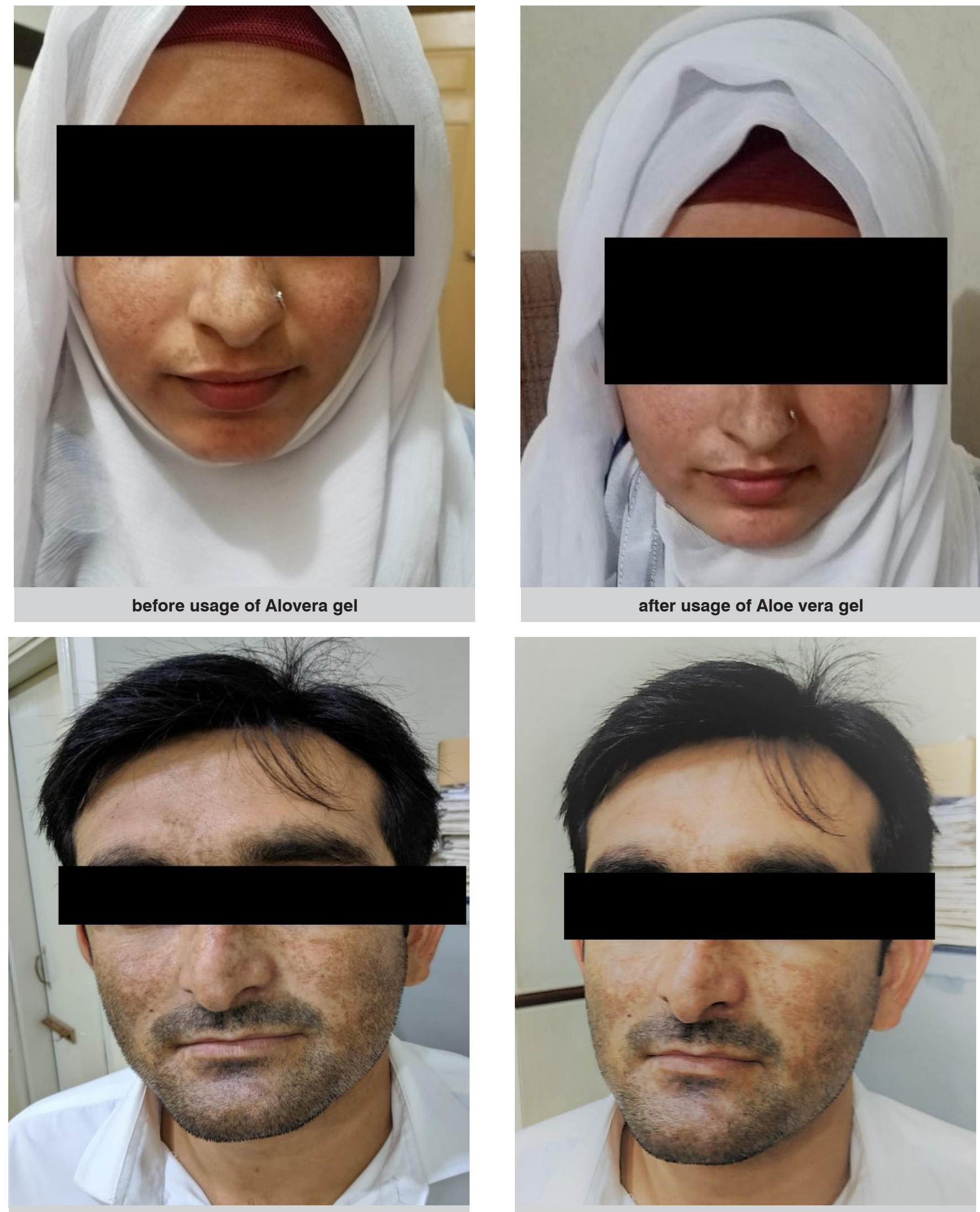

Before usage of undecylenoyl phenylalanine 2\%

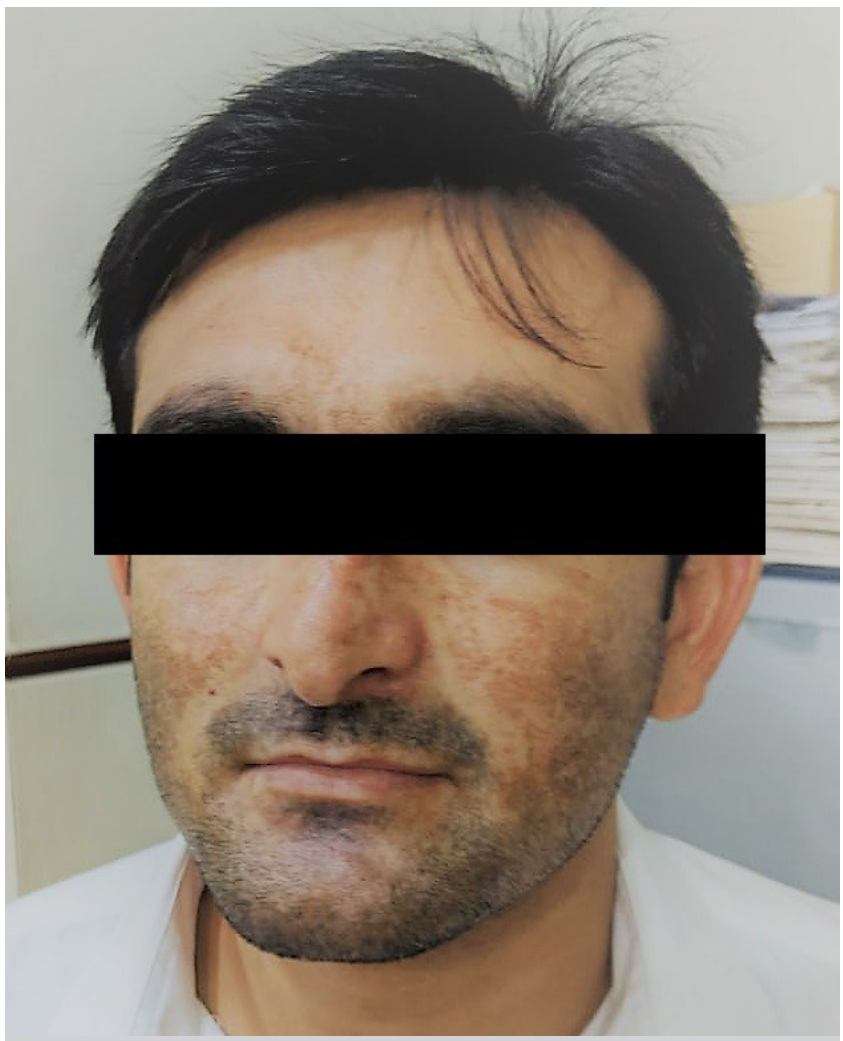

After usage of undecylenoyl phenylalanine $2 \%$

Professional Med J 2020;27(8):1770-1776. 


\begin{tabular}{|c|c|c|c|c|}
\hline & \multirow[b]{2}{*}{ Weeks } & \multicolumn{3}{|c|}{ Modified MASI Score } \\
\hline & & Mean & SD & $\begin{array}{c}p \text { - value by } \\
\text { One way } \\
\text { ANOVA }\end{array}$ \\
\hline \multirow{4}{*}{$\begin{array}{l}\text { Aloe vera leaf } \\
\text { gel }\end{array}$} & 0 week & 17.81 & 1.67 & \\
\hline & 4 week & 17.5 & 1.84 & \\
\hline & 8 week & 17.45 & 1.79 & 0.535 \\
\hline & 12 week & 17.36 & 3.28 & \\
\hline \multirow{4}{*}{$\begin{array}{l}\text { Undecylenoyl } \\
\text { phenylalanine } \\
2 \%\end{array}$} & 0 week & 18.13 & 1.54 & \\
\hline & 4 week & 14.1 & 1.66 & \\
\hline & 8 week & 9.75 & 1.24 & $<0.001$ \\
\hline & 12 week & 4.95 & 1.13 & \\
\hline
\end{tabular}

Comparison of modified MASI score after treatment with Aloe vera leaf gel and undecylenoyl phenylalanine $2 \%$. $(n=60)$

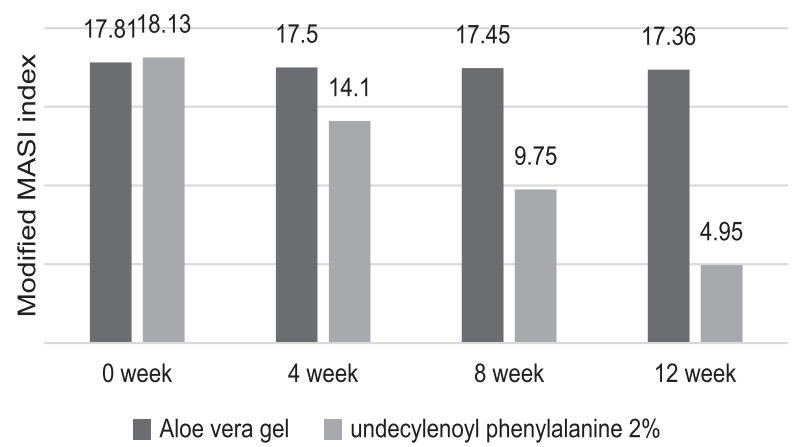

Figure-1. Comparison of modified MASI score after treatment with Aloe vera leaf gel and undecylenoyl phenylalanine $2 \%$. $(n=60)$

\section{DISCUSSION}

Melasma is a very prevalent and recurrent problem of the modern world ${ }^{17}$ which is more common in females than men. ${ }^{18}$ Incidence variability of melasma among regions from 4 to $40 \%$ of the population. ${ }^{19}$ Melasma has significant impact on the patient's emotional health and social existence. During the previous few years, different quality of life measures have been exercised to establish the way that melasma impacted patient's day to day life.
These include the Melasma Quality of Life (MELASQoL) scale and Dermatology Life Quality Index (DLQI) and Skindex surveys. Results from various studies were concordant in the fact that melasma is associated with decreased quality of life. ${ }^{5}$ UV light, inflammation and excess female hormones are aggravating factor along with genetic predisposition. ${ }^{20}$ The aim of a melasma therapy is to reduce pigment formation and enhance elimination of melanin from body. Different kinds of topical melanin inhibitors, laser and light-based devices enhance melanin elimination. A multifocal treatment strategy aiming at both reduction of melanin production and its rapid removal is imperative to attain equilibrium and disease reoccurrence. ${ }^{17,21,22}$

Nowadays, many newer herbal agents are available in market and boost about their proven efficacy in treatment of melasma. ${ }^{9}$ So, we compared Aloe vera leaf gel with undecylenoyl phenylalanine $2 \%$.

In a study conducted in 2017, Aloe vera leaf gel extract (AGE) and liposome-encapsulated AGE was applied to 90 patients each for treatment of melasma. After 5 weeks of therapy in these pregnant women, liposomal-AGE treatment group showed 32\% improvement whereas Aloe vera leaf gel extract (AGE) only showed $10 \%$ improvement. ${ }^{14}$ This is comparable to our study, which showed that Aloe vera leaf gel alone showed insignificant ( $p$-value of 0.535 ) improvement of Modified MASI index in patients with melasma.

Undecylenoyl phenylalanine $2 \%$ is a novel agent used nowadays to treat melasma. In a recent study undecylenoyl phenylalanine $2 \%$ achieved a significant lightening of melasma lesions in 20 patients on their first follow-up visit at 4 weeks with statistical significance of $p<0.001 .^{23}$ In our study, 60 patients showed similar significant improvement of Modified MASI score with undecylenoyl phenylalanine $2 \%$ with $p$-value of $<0.001$. This in turn concluded that Aloe vera leaf gel is not an effective treatment for melasma whereas topical undecylenoyl phenylalanine $2 \%$ is very efficacious in patient. 


\section{CONCLUSION}

Undecylenoyl phenylalanine may represent an efficious and beneficial therapy of melasma. Herbal agents which contain Aloe vera who falsely claim that they are effective should be discouraged to treat melasma.

Copyright@ 19 Mar, 2020.

\section{REFRENCES}

1. Pandya A, Berneburg M, Ortonne JP, Picardo M. Guidelines for clinical trials in melasma. British Journal of Dermatology. 2006; 156:21-8.

2. Passeron T, Picardo M. Melasma, a photoaging disorder. Pigment cell \& melanoma research. 2018; $31(4): 461-5$.

3. Halder S, Halder A, Nag SC, Sarkar P. Melasma in the people of Sub-Himalayan region of Eastern India. Journal of Pakistan Association of Dermatology. 2016; 23(2):139-42.

4. Sehgal VN, Verma P, Srivastava G, Aggarwal AK, Verma S. Melasma: Treatment strategy. Journal of Cosmetic and Laser Therapy. 2011; 13(6):265-79.

5. Katsambas A, Soura E. Quality of Life in Melasma. Melasma and vitiligo in brown skin: Springer; 2017. p. 169-75.

6. Ikino JK, Nunes DH, Silva VPMd, Fröde TS, Sens MM. Melasma and assessment of the quality of life in Brazilian women. Anais brasileiros de dermatologia. 2015; 90(2):196-200.

7. Suggs AK, Hamill SS, Friedman PM, editors. Melasma: Update on management. Seminars in cutaneous medicine and surgery; 2018.

8. Kimbrough-Green CK, Griffiths CE, Finkel LJ, Hamilton $\mathrm{TA}$, Bulengo-Ransby SM, Ellis $\mathrm{CN}$, et al. Topical retinoic acid (tretinoin) for melasma in black patients: A vehicle-controlled clinical trial. Archives of dermatology. 1994; 130(6):727-33.

9. Saha R. Cosmeceuticals and herbal drugs: Practical uses. International Journal of Pharmaceutical Sciences and Research. 2012; 3(1):59.

10. Mahor G, Ali SA. Recent update on the medicinal properties and use of Aloe vera in the treatment of various ailments. Biosci Biotechnol Res Commun. 2016; 9(2):277-92.
11. Hajheydari Z, Saeedi M, Morteza-Semnani K, Soltani A. Effect of Aloe vera topical gel combined with tretinoin in treatment of mild and moderate acne vulgaris: A randomized, double-blind, prospective trial. Journal of Dermatological Treatment. 2014; 25(2):123-9.

12. Eshghi F, Hosseinimehr SJ, Rahmani N, Khademloo $M$, Norozi MS, Hojati O. Effects of Aloe vera cream on posthemorrhoidectomy pain and wound healing: Results of a randomized, blind, placebo-control study. The Journal of Alternative and Complementary Medicine. 2010; 16(6):647-50.

13. Finberg MJ, Muntingh GL, van Rensburg C. A comparison of the leaf gel extracts of Aloe ferox and Aloe vera in the topical treatment of atopic dermatitis in Balb/c mice. Inflammopharmacology. 2015; 23(6):337-41.

14. Ghafarzadeh M, Eatemadi A. Clinical efficacy of liposome-encapsulated Aloe vera on melasma treatment during pregnancy. Journal of Cosmetic and Laser Therapy. 2017; 19(3):181-7.

15. Olejnik A, Glowka A, Nowak I. Release studies of undecylenoyl phenylalanine from topical formulations. Saudi pharmaceutical journal. 2018; 26(5):709-18.

16. Arain $A Q$, Hussain $M$, Chiragh $S$. Effect of different doses of aloe vera versus indomethacin on sodium and water retention in healthy rats. Journal of Postgraduate Medical Institute (Peshawar-Pakistan). 2017; 31(3).

17. Ogbechie-Godec OA, Elbuluk N. Melasma: An upto-date comprehensive review. Dermatology and therapy. 2017; 7(3):305-18.

18. Sivayathorn A. Melasma in orientals. Clinical Drug Investigation. 1995; 10(2):34-40.

19. Cestari T, Peruzzo J, Giongo N. Definition, incidence, and etiology of melasma in brown skin. Melasma and Vitiligo in Brown Skin: Springer; 2017. p. 13-9.

20. Lee AY. Recent progress in melasma pathogenesis. Pigment cell \& melanoma research. 2015; 28(6):648-60.

21. Dunbar S, Posnick D, Bloom B, Elias C, Zito P, Goldberg DJ. Energy-based device treatment of melasma: An update and review of the literature. Journal of Cosmetic and Laser Therapy. 2017; 19(1):2-12.

22. Katsambas A, Antoniou C. Melasma. Classification and treatment. Journal of the European Academy of Dermatology and Venereology. 1995; 4(3):217-23. 
23. Katoulis A, Alevizou A, Soura E, Mantas N, Bozi E, Gregoriou S, et al. A double $\square$ blind vehicle $\square$ controlled study of a preparation containing undecylenoyl phenylalanine $2 \%$ in the treatment of melasma in females. Journal of cosmetic dermatology. 2014; 13(2):86-90.

\begin{tabular}{|c|c|c|c|}
\hline \multicolumn{4}{|c|}{ AUTHORSHIP AND CONTRIBUTION DECLARATION } \\
\hline Sr. \# & Author(s) Full Name & Contribution to the paper & Author(s) Signature \\
\hline 1 & Farwa Naqvi & Abstract, Literature review \& & \\
\hline & & Methodology. & \\
\hline 2 & Zaib & Performed experiments \& & \\
\hline 3 & Iram Imran & Performed experiments & \\
\hline & Ahmod Amin Khon & compile \& analyze resutls. & \\
\hline 4 & $\begin{array}{l}\text { Ahmed Amin Khan } \\
\text { Faraz }\end{array}$ & $\begin{array}{l}\text { Typographical error \& brief } \\
\text { review. }\end{array}$ & \\
\hline 5 & Tahira Tabussam & $\begin{array}{l}\text { Typographical error \& brief } \\
\text { review. }\end{array}$ & \\
\hline 6 & Sultan Sikandar & $\begin{array}{l}\text { Literature review Helped in } \\
\text { finding results. }\end{array}$ & \\
\hline
\end{tabular}

